\title{
Erratum to: Dissolved organic carbon in permafrost regions: A review
}

\author{
Qiang MA ${ }^{1,2}$, Huijun $\mathrm{JIN}^{1,3^{*}}$, Congrong $\mathrm{YU}^{4}$ \& Victor F. BENSE ${ }^{1,5 \dagger}$ \\ ${ }^{1}$ State Key Laboratory of Frozen Soils Engineering, Northwest Institute of Eco-Environment and Resources, Chinese Academy of Sciences, \\ Lanzhou 730000, China; \\ ${ }^{2}$ College of Resources and Environment University of Chinese Academy of Sciences, Beijing 100049, China; \\ ${ }^{3}$ School of Civil Engineering, Harbin Institute of Technology, Harbin 150090, China; \\ ${ }^{4}$ State Key Laboratory of Hydrology-Water Resources and Hydraulic Engineering, Hohai University, Nanjing 210000, China; \\ ${ }^{5}$ Hydrology and Quantitative Water Management Group, Department of Environmental Sciences, Wageningen University, Wageningen 6700 , \\ The Netherlands
}

Citation: Ma Q, Jin H, Yu C, Benst V F. 2019. Erratum to: Dissolved organic carbon in permafrost regions: A review. Science China Earth Sciences, 62: 750, https://doi.org/10.1007/s11430-019-9339-9

The article Dissolved organic carbon in permafrost regions: A review, written by Qiang MA, Huijun JIN, Congrong YU, and Victor F. BENSE, was erroneously originally published online without open access. After publication in Vol 62 Issue 2 this was corrected and the article is now an open access publication. Therefore, the copyright of the article has been changed to (c) The Author(s) 2019 and the article is forthwith distributed under the terms of the Creative Commons Attribution 4.0 International License (http://creativecommons.org/licenses/by/4.0/), which permits use, duplication, adaptation, distribution and reproduction in any medium or format, as long as you give appropriate credit to the original author(s) and the source, provide a link to the Creative Commons license, and indicate if changes were made.

The original article has been corrected.

Open Access This article is distributed under the terms of the Creative Commons Attribution 4.0 International License (http://creativecommons.org/licenses/by/4.0/), which permits use, duplication, adaptation, distribution and reproduction in any medium or format, as long as you give appropriate credit to the original author(s) and the source, provide a link to the Creative Commons license and indicate if changes were made.

The online version of the original article can be found at https://doi.org/10.1007/s11430-018-9309-6.

\footnotetext{
* Corresponding author (email: hjjin@1zb.ac.cn)

$\dagger$ Corresponding author (email: victor.bense@wur.nl)
} 